\title{
Lapse of rights connected with assignment of legal claims, problematic issues and their solution
}

\author{
V. Nemenova \\ The University of Economics and Culture, Riga, Latvia
}

\begin{abstract}
Impact of transfer of legal claim on the destiny of rights security and connected claims may differ. The aim of the article is to analyze the transfer of rights connected with transferred legal claims, to survey the problematic issues and to suggest methods of their solution. The author analyzes legal norms, judicial practice of Germany, Switzerland, Russia and Latvia, as well as opinions of law scientists about transfer of guarantee, lien, penalty, interest, losses compensation and agreement of court of arbitration in connection with assigned legal claims. The author offers her own point of view regarding the issue and suggestions on amendments in the legal acts.
\end{abstract}

Key words: cession; guarantee; pledge; penalty; interest.

\section{Introduction}

Consequences of cession (assignment) are always limited with lapse of right to legal claims.

The scope of rights under transfer according to the Civil Law of Latvia is defined in Article 1806:

"The Assignee does not acquire more or bigger rights with cession than the assignor used to have before, but the claim itself goes to him with all rights belonging to it and existing at the moment of cession, even if they are justified basing on the personal benevolence towards the assignor, so far as they have no directly defined exception from this condition.

Unpaid claim interest if it is not directly contracted also goes to the assignee.

The assignor shall transfer to the assignee everything that suits as claim evidence or that may facilitate its collection, as well as everything that he has received from the debtor already after cession."

A. Tuhrs [1] states that transfer of rights connected with legal claims to the assignee is the cession agreement's legal concomitant consequences, which commence also in case when the agreement has nothing mentioned about it. True, their commencement may be excluded by agreement between the assignor and the assignee or agreement between the creditor and the person providing security (for instance, creditor and guarantor agree that the claim against the guarantor will not be transferred to other person transferring the main legal claims).

The impact of transfer of legal claims on the destiny of rights security may be different. 
Aim: to analyze the transfer of rights connected with the transferred legal claims, to study the issues and offer their ways of solution.

\section{Discussion and results}

Ensuring the claim under transfer with security, the new creditor receives both the conditioned and the actual claim towards the guarantor. Many authors [2-5] believe that in case when the cession to the guarantor is excluded, it is terminated. However, the issue on the destiny of claim towards the guarantor in case of its exclusion from the secured rights is closely connected with the issue on the possibility of isolated transfer of this claim. Legal scholars of Germany and Switzerland $[1,6,7]$ believe that this issue shall be resolved affirmatively, therefore it is necessary to allow it as possible for an assignor to keep the claim against the guarantor in case of isolated transfer of the main claim.

Guarantee is the duty undertaken by the agreement to bear responsibility towards the creditor for the debt of the third person, however, without releasing the latter from his debt [8]. The guarantee, like the mortgage rights, is the type of rights reinforcement. Still, unlike the mortgage agreement, in case of guarantee a separate agreement with the third person on claim security is concluded.

Direct participants of guarantee establishment are warrantor and creditor. The main debtor stays aside. It arises from here that the main debtor has not only no necessity to participate in guarantee establishment, but also to know about it at all [9].

Although the guarantee is closely connected with the debt liability, its establishment, scope and termination, it is a separate contractual liability, which in individual cases may exist without the basic debt [8], as well as the guarantee claim term and fulfillment may not coincide with the term of execution of debt defined in the agreement. Herewith the issue is disputable regarding the guarantee transfer in case of cession, as with cession only the claim is transferred against the debtor, and not the whole contractual relation and agreements, which have been concluded with the third persons. Likewise problematic issue may be noticed in implementation of cession execution, as, for example, the assignor must duly inform the debtor about the cession [8]; in this case the guarantor may fulfill the liability for the assignor, without knowing about the claim transfer and independently from the debtor.

A. Grütups states in the comments of the Civil Law that there is no law, which would require that the guarantee must be in force only against strictly defined creditor. As the guarantee is an accompanying liability, which (usually) does not exist permanently, but accompanies the (main) debt liability, but the latter may be transferred to other person, then there is no grounds to think that in this case the guarantee would be discharged, even more because usually the guarantor sees no difference about any specific creditor he bears responsibility as a guarantor [10]. The author believes that one shall agree with the given comment, as when the guarantee does not go with debt claim in case of cession, the scope and security of the claim subject would be considerably changed.

The guarantor's rights arising from the guarantee contract may be the legal claim transfer according to the Article 1793 of the Civil Law, because according to the Article 1704 of the Civil Law, in what amount the guarantor satisfies the creditor, in that amount he receives claims of the latter towards the main debtor. In this case automatic transfer of legal claims is fulfilled from the creditor to the guarantor, without will expression of the creditor, and the guarantor owns regress rights towards the debtor.

Alongside with other secured rights, also the lien goes to the assignee.

One more accompanying related right, which goes to the assignor, is legal transfer of lien in case of claim cession basing on the Article 1278 of the Civil Law, which defines that 
the lien is such a right to foreign object, on the grounds of which this object ensures to the creditor his claim in such order, that he may get from it payment of this claim.

The lien being the real right allows the pledge using the pledged property as the debt liability security because he may receive debt payment from the pledged thing itself or money received for its sale [11]. The lien shall be recognized as related right; and as such in case of cession follows the main claim. As the mortgage being the lien is entered into the Land Book, then, unlike other cases, for example, in case of renewal, to enter cession into the Land Book, no consent of mortgager is needed. The assignee may request, depending on the conditions of pledge agreement, incontestable compulsory execution or real estate sale at free auction through court." [11]

The Commercial Pledge Law [12] regulates rules on transfer of commercial pledge in case of secured claim cession. First part of Article 35 of the Commercial Pledge Law defines that assigning the secured claim, the assignee receives also all rights of the person taking commercial pledge, unless the assignor and the assignee have not agreed otherwise, and the second part of the article of the mentioned law defines that regarding conclusion of cession agreement the person holding commercial pledge register makes a note on the grounds of a written notification of the person taking commercial pledge.

Penalty is one of the most often used types of reinforcement of law of obligation for related guarantee, pledge (mortgage) and earnest money. Penalty regulation in the Article 716-1724. ${ }^{1}$ of the Civil Law gives wide opportunities to define it in different ways and volumes, and exactly the penalty scope issues become the basic dispute subject of many cases under consideration at the court. There should be a large number of cases of application of accumulated "expressed unjust penalties" to start considering, what in reality are the penalty functions, what is the penalty application in good faith and whether the fact that the law does not define the rule on penalty decrease means that any exceptions are banned. The searches for a new approach were facilitated also by looking-through of documents of the European Union and the European Council, civil law unification projects, laws and practice of other countries. Judicature turn took place, which initially was marked in the resolution of Senate from 2004 in the Case No. SKC-441, resolution from 2005 in the Case No. SKC-48 and resolution from 2007 in the Case No. SPC-43 and explicitly justified by the resolution of the Senate from May 14, 2008 in the Case No. SKC-212. In relation to the court's possibility to fight against excessive penalties, the practice and Senate's judicature has developed, overtaking the amendments in the Civil Law (Article 1724 ${ }^{1}$ ), which generally gives rights to decrease the penalty if it is excessive [13].

The lawmaker has registered the rights of the court to decrease the penalty up to reasonable amount, if it is excessive, also in the Article $1724 .^{1}$ of the Civil Law, as amended on June 4, 2009, which have come into effect on July 1, 2009.

By amendments from June 20, 2013, which came into effect on January 1, 2014, the Article 1716 of the Civil Law defines that the penalty for failure to timely (within the term) fulfill liabilities, may be increasing, however, without exceeding 10 percent of the property value of failure to fulfill the delayed liabilities.

The most important thing is that the penalty institute must correspond to the civil law task and the idea of justice, like the European Union's policy and attitude towards the penalty sanctions in private law. While developing the amendments, the lawmaker pointed that the current legal regulation facilitates the social stratification tendencies, which leads to a part of society finding itself under yoke of debts when riches of other people multiply.

Civil Law amendments, which have been made by the law of Saeima from June 20, 2013 and have come into effect on January 1, 2014, shall be considered one of the most considerable amendments in the part of Law of Obligation since renewal of the Civil Law performance. They will sharply change the meaning of penalty in civil circulation and shall 
be considered a step of lawmaker in civil law modernization and even getting closer to the system of Anglo-Saxon law [14].

In Great Britain and other Anglo-Saxon law system countries, like Ireland, the USA, Australia and Canada, there are mutually equal rules in relation to the penalty, namely, the penalty, which actually performs the function of penalty fee (penalty), is forbidden. Only penalty is allowed, which performs the function of loss compensation. Currently, in the American law, two criteria are formulated, which shall come true for the penalty to not be admitted the penalty fee (penalty), namely, first of all, it cannot be disproportionate in relation to potential or actual losses, which have arisen due to failure to fulfill liabilities. Second-of-all, potential or actual losses must be clearly provable [15]. Similar approach was used in the case Dunlop Pneumatic Tyre Co Ltd v New Garage and Motor Co Ltd. [16], which is one of the significant court judgments in cases on penalties in Great Britain. In the mentioned case, the House of Lords defined the principles how to define, whether the penalty's clause is actually a punishment and thus it shall be acknowledged inapplicable. Australia's Supreme Court has also referred to this case within the case Ringrow Pty Ltd $v$ BP Australia Pty Ltd. [17], as well as Irelands Supreme Court in the case O"Donnell v Truck and Machinery Sales Limited [18]. Canadian Supreme Court has used similar approach in the case Elsley v. J.G. Collins Ins Agencies [19], in which it rejected higher compensation for failure to observe the agreement provisions than the losses actually caused by failure to fulfill liabilities [20].

Payment of penalty correlates with creditor's losses.

The penalty is the purest self-enrichment at the expense of the debtor, if it is defined in the amount, which considerably exceeds the loss of profit caused by non-fulfillment [21].

Civil Case Department of the Supreme Court's Senate of the Republic of Latvia has stated [22] that the penalty has the function of punishment and loss compensation. In cases when it is concluded from the case that the penalty by its amount, in comparison to the possible losses caused by violation, perform mostly the function of punishment, its application shall be evaluated according to the general principles of application of legal means with nature of punishment, including principles of punishment proportionality and justice. The general law principles are generally accepted guidelines arising from the legal state principle, main regulations, which the respective law system or sector bases on. The general law principles are unwritten primary rights of the European Union. By cancellation of agreement, the grounds for further application of penalty provided in it is lost, still, it does not exclude the rights to demand already accumulated penalty.

The performance provided by penalty is encouragement of the debtor to fulfill liabilities, threatening to impose additional duties on him. That is why the security function is performed by it only until commencement of condicio juris. As the rights, which ensure liability fulfillment and which go to the assignee in case of main claim transfer, only the conditioned claim for penalty payment is put forward. Already existing claim on penalty payment in case of transfer of main legal claims does not go to the assignee ipso jure, like some civil law scientists believe [6,7], but it is kept by the assignor [1, 23-26].

The Civil Case Department of the Senate of Superior Court of the Republic of Latvia has stated [27] that if the contracted rights of contract termination before term are used, when the contract is terminated before term, the legal grounds disappears also regarding calculation and collection of contracted interest and penalty according to the contract provisions, because there is no legal grounds for their application after contract termination. The contracted interest and penalty in cases, when the party legally withdraws from the contract, shall be compensated till the moment, when the contract ceases to exist.

The claim on losses compensation has permanent nature in relation to the rights, from the violation of which it has arisen. This claim continues to exist even if the violated rights have been terminated, and in case of their alienation is not transferred ipso jure to the new 
rights owner, but is alienated with a separate cession agreement [28]. The German legal scholars $[5,29,30]$ state that the claim for losses compensation, which have arisen before cession debtor term delay, in case of transfer of the delayed legal claims is not transferred to the assignee as the rights related to it, but is kept by the assignor.

Analogous approach shall be used defining the destiny of claims arising at the moment of assignment regarding payment of penalty and interest for use of foreign money, which refers to the claim on loss compensation, like the claim on compensation payment.

It is necessary to pay special attention to the instruction given in Part 2 of Article 1806 of the Civil Law, that the unpaid claim interest, even if it is not directly contracted, is also transferred to the assignee.

Such a definition causes many questions. First of all, it is not explained, what interest we speak about - interest on late payments or interest that must be paid for use of money, which is granted according to the loan agreement, credit agreement, as commercial credit etc. Such differentiation in relation to Part 2 of Article 1806 of the Civil Law should be performed, because it is necessary to define the destiny of claim on unpaid interest like it is done regarding the claims on caused losses, when the debtor does not follow the payment term, as well as for payable penalty - if there is no separate agreement, they all are kept by the assignor. Second of all, hardly any connection between the right to unpaid interest and the transferred legal claims can be seen, which would request their joint transfer to the assignee. If BGB in this issue has no special instructions, the German civil law scientists [5, 24] usually state that the interest are due to the previous creditor with the commenced term.

In relation to the issue on mutual interconnection of interest and losses - the professor K. Torgāns states that the answer shall be sought in Article 1788 of the Civil Law, in which it is clearly stated that the interest by its economical nature is the compensation for uncollected profit, i.e., a component of losses. It is represented also in the Regulation 2000/35/EEK (submission 17), which states that the steps to be taken shall be implemented, without affecting the regulations of countries, according to which the state judge may grant to the creditor additional remuneration for losses caused by late payments of the debtor, taking into account that these costs may already be compensated with interest of late payments. Especially one should mark out that the interest serves for compensation of costs, i.e., losses. It means that the interest payments serve for compensation of losses, and thus false interpretation of Article 1722 of the Civil Law must be stopped, which sometimes appears in the statements of claim and other legal documents [20].

The perspectives of claim circulation largely depend on the assignee's real possibilities to implement his rights in relation to the acquired claim, including also by force. In this case, it is required to separately examine the transfer of jurisdiction agreement rights to the assignee. In law literature, different points of view regarding this issue may be found. So, V.A. Belovs, analyzing the legal acts of the Russian Federation, assumes that the proviso made by the court of appeals (court of arbitration) is not either condition of transferred rights or condition of their implementation. It forms the condition of protection of violated rights that is why it is not affected by the Article 384 of the Civil Code of the Russian Federation, which refers only to rights in their normal status. As the assignor bears no responsibility for excessive acts during rights implementation, it is unjust to impose to the assignee a burden to observe the protection conditions, which the assignor has agreed on. That is why the rights according to the arbitrage proviso go to the assignee only in case if it is directly provided for by the assignment agreement [31].

Opposite opinion in this issue belongs to L.A. Novoselova, who believes that the forced defense possibility is an integral element of subjective rights. That is why, acquiring the rights to demand, the assignee hereby, according to general conditions, undertakes a duty to follow the condition of forced implementation of rights [32]. R.S. Bevzenko also assumes that: "Consequent application of the opinion to the right of filing a claim as to subjective 
material civil law element must inevitably lead to a conclusion that in case of rights transfer proviso performance remains regarding disputes' contractual jurisdiction connected with execution of transferable claim" [33].

Many Russian law scientists see this position as a more consequent, as discussing the issue on the destiny of arbitrage proviso, in the first place it is necessary to consider the consequences of one or other decision from the point of view of the debtor's status constancy provision in case of transfer. From these positions, exclusion of the assignee from the field of activity of the arbitrage proviso considerably affects the debtor's status, who has agreed with the defined conditions regarding claim set forth to him. And vice versa - the assignee, concluding an assignment agreement, can look through the agreement's conditions, from which the transferable claim has arisen. If he acquires these rights for his possession, it means that he considers the rules of its implementation and protection acceptable that is why he does not need any protection in this situation.

It is necessary to note that in the Russian Federation this position on following of arbitrage disclaimer the rights under transfer (claim) in practical aspect is not disputed by anyone.

A more different approach, which is connected with the arbitrage court clause in case of cession, is used in the judicial practice in Latvia.

In Latvia's practice, courts of arbitration often satisfied the claims of collection of assignees' debts, where the assignee has not been a member of agreement of court of arbitration, and later it was asked to the district court to issue a writ of execution for forced execution of the decision, which quite often was satisfied. The main argument of the Senate, cancelling the district court's judgments on issue of writs of execution for forced execution of resolutions made by courts of arbitration, is the Article 1800 of the Civil Law, basing it by the fact that transition of the regulation of court of arbitration (clause of court of arbitration) is impossible, because the assignee is not the party of the agreement (from which the liability has arisen), as well as he is not the members of agreement of court of arbitration.

AT Civil Cases Senate's opinion has gained support in law doctrine. Senate's opinion has been supported by such civil law scientists like E. Moris [34] and L. Lapsa [35].

Opposite opinions are also met in the Latvian legal literature. Contradictory opinions on the border of assignment being a specific claim in the legal transaction state that this issue is not unambiguous. The authors conclude that in case if the assignment agreement includes a clause of court of arbitration, then, taking the principles of legal transaction as a free agreement included into the Civil Law into account, the assignee gets also the rights to resolve a dispute, which is connected with the assigned claim, at the court of arbitration. Besides the authors believe that this condition will not worsen the debtor's condition, because the agreement on dispute resolution by the court of arbitration has been achieved already between the assignor and the debtor. Analyzing the procedure of court of arbitration, A. Mikelsone has noted that assigning rights, the liabilities previously undertaken by the creditor (assignor) and arising from the respective transaction are binding to the assignee. If the assignor has agreed on transfer of the possible dispute to the court of arbitration, these regulations are in force and they shall be executed also by the assignee [36].

On September 11, 2014, a new Arbitrage Court Law was adopted, which came into effect on January 1, 2015, which gained wide resonance among the Latvian law scientists during development and adoption of draft law [37-43]. The author positively evaluated the fact that the lawmaker has included the long-expected legal norm into the Part 4 of Article 13 of the Arbitrage Court Law: "Assigning the claim, the assignee receives the legal claims, but not the clause of arbitrage court included into the contract on consideration of civil dispute by the arbitrage court". 


\section{Conclusion}

Securing the claim under transfer with a guarantee, the new creditor receives both the conditions and the actual claim against the guarantor. Together with other secured rights the assignee receives also the lien.

As the rights ensuring liability fulfillment and going to the assignee in case of transfer of the main claim, only the conditioned claim for penalty payment is brought forward. The author offers to refer the penalty to non-assignable claims and respectively to change the legal norms of the Civil Law.

The claim on losses compensation has permanent nature in relation to the rights, from violation of which it has arisen. This claim continues to exist, even if the violated rights have been terminated, and in case of their alienation does not go ipso jure to the new rights owner, but is alienated with a separate cession agreement.

The interest by its economical nature is the compensation for uncollected profit, i.e., a component of losses. The author suggests expressing the second sentence of Article 1806 of the Civil Law in the following wording: The unpaid claim interest, which has payment term already commenced, if the contract does not define otherwise, is kept by the assignor.

The Arbitrage Court Law adopted on September 11, 2014, which came into effect on January 1, 2015, shall be also positively evaluated. Its Part 4 of Article 13 contains a longexpected legal norm: "Assigning the claim, the assignee receives the legal claims, but not the clause of arbitrage court included into the contract on consideration of civil dispute by the arbitrage court".

\section{References}

1. A. Tuhr (1925). Allgemeiner Teil des schweizerischen Oblihationenrechts. Halbbd.2. Tübingen

2. O. Gierke (1917). Deutsches Privatrecht. Bd.3.München und Berlin

3. H.G. Lambsdorff, B. Skova (1994). Handbuch des Bürgschaftsrechts. München

4. G. Lüke (1995). Grundfragen des Zessionrechts//Juristische Schulung

5. O. Palandt (2004). Bürgerliches Gesetzbuch. Kurzkommentar. 63 Aufl. München

6. L. Enneccerus, Th. Kipp, M. Wolff (1927) Lehrbuch des bürgerlichen Rechts. Marburg

7. F. Leonhard (1929). Allgemeines Schuldrecht des BGB. München und Leipzig

8. Civillikums. Ceturtā daḷa. Saistību tiesības. / Latvijas Republikas likums. Pieñemts Latvijas Republikas Saeimā 28.01.1937.; stājies spēkā 01.03.1993. Ziṇotājs Nr.4, 1992.gada 30.janvāris

9. Сводъ гражданских узаконений губерний Прибалтийских т. 2. (1914). Сост. В. Буковский

10. Autoru kolektīvs prof. K. Torgāna red.(2000). Latvijas Republikas Civillikuma komentāri. Saistību tiesības. Rīga: Mans īpašums

11. G. Višņakova, K. Balodis (1998). Latvijas Republikas Civillikuma komentāri. Lietas. Valdījums. Tiesības uz svešu lietu. Rīga: Mans īpašums

12. Komerckīlas likums. 21.10.1998 / Latvijas Republikas likums. Pieñemts Latvijas Republikas Saeimā 21.10.1998.; stājies spēkā 01.03.1999. Latvijas Vēstnesis Nr.337/338. 11.11.1998

13. Tiesu prakse līgumsodu piemērošanā, http://www.at.gov.lv/.../Apkopoj_ligumsodi_5.11.2013.do

14. K. Freimanis, R. Niedra. Līgumsodu griestu noteikšana Eiropā: salīdzinošs pētījums, http://www.juristavards.1v/doc.php?id=263853 
15. Social Transformations in Contemporary Societi clauses within different legal systems, 2013. http://www.stics.mruni.eu/wp-content/uploads/ 2013/06/153-162.pdf

16. Dumlop Pneumatic Tyre Co Ltd v New Garage and Motor Co Ltd, (1915) AC79. http://www.bailii.org/uk/cases/UKHL/1914/1.html

17. Ringrow Rty Ltd v BP Australia Pty Ltd (2005) HCA 71

18. O“Donell v Truck and Machinery Sales Limited 19984 IR 191

19. Elsley v. J.G. Collins Ins Agencies, (1978) 2 S.C.R. http: //www . scccsc.lexum.com/decisia-scc-csc/scc-csc/en/item/2597/ index.do

20. K. Freimanis, R. Niedra Līgumsodu griestu noteikšana Eiropā: salīdzinošs pētījums . Pieejams: http: / /www.juristavards.1v/doc.php?id=263853

21. K. Torgāns Līgumsoda anomālijas Direktīvas 2011/7/ES normu kontekstā. Piejams: http: //www . juristavards. Iv/doc . php?id= $252065 \&$ show $=$ true

22. Latvijas Republikas Augstākās tiesas Senāta Civillietu departamenta 2008. gada 14.maija Spriedums Lietā Nr. SKC - 212/2008

23. P. Oertmann (1906). Das Recht der Schuldverhältnisse. 2 Aufl. Berlin

24. K.W. Nörr, R. Scheyhing, W. Pöggeler (1999). Sukzessionen: Forderungszession, Vertragsübernahme, Schuldübernahme. 2. Aufl. Tübingen

25. Е. А. Крашенинников (1999). Основные вопросы уступки требования // Очерки по торговому праву: Сб. науч. тр. / Под ред. Е. А. Крашенинникова. Вып. 6. Ярославль

26. В. В. Грачев (2006). Притязание на неустойку // Очерки по торговому праву. Ярославль, Вып. 13

27. Latvijas Republikas Augstākās tiesas Senāta Civillietu departamenta 2013.gada 30.janvāra Spriedums lietā Nr. SKC-644/2013. http://at.gov.lv/files/uploads/files/archive/department1/ 2013/644-skc-2013.doc

28. М.М. Агарков (2002). Избранные труды по гражданскому праву. в 2-х т. Москва

29. J. Gernhuber (1974). Synallagma und Zession// Festschrift für Ludwig Raiser. Tübingen

30. J. Esser, E. Schmidt (1993). Schuldrecht: ein Lehrbuch. Bd. 1. Teilbd. 7 Aufl. Heidelberg

31. В. А. Белов (2000). Сингулярное правопреемство в обязательстве. М.: ЮрИнфоР

32. Л. А. Новоселова (2003). Сделки уступки права (требования) в коммерческой практике. Факторинг. Москва. Статут

33. Р. С. Бевзенко (2009). Некоторые вопросы судебной защиты права при уступке требований // Закон. № 10

34. E. Moris (2005). Cedētas tiek prasījuma tiesības, bet nevis strīda izskatīšanas kārtība. Jurista Vārds, 12.04.2005, Nr.368

35. J. Lapsa. Par jauno šķīējtiesu likumu. Pieejams: http://vpstiesa. Iv/ page/lv/par-jauno-skirejtiesu-likumu

36. A. Miḳelsone (2005). Par izmaiṇām šķ̄īējtiesas procesā. Jurista Vārds. 15.03.2005/NR.10

37. G. Litvins (2014). Šḳ̄īējtiesas kompetenci jāḷauj apstrīdēt vispārējās jurisdikcijas tiesā. Jurista Vārds, 9.12.2014/Nr.48 (850)

38. T. Krūmiņš (2014). Šḳīējtiesas izṇēmums Briseles režīmā. Jurista Vārds 7.10.2014/NR. 39 (841) 
39. I. Kucina (2014). Par šķ̄īējtiesu regulējumu un tā pilnveidi. Jurista vārds, 3.06.2014/NR. 22 (824)

40. S. Bērtaitis (2014). Valsts nedrīkst piel̦aut prettiesisku praksi strīdu alternatīvajā risināšanā. Jurista Vārds, 3.06.2014/NR. 22 (824)

41. J. Lapsa (2014). Šķīējtiesu regulējuma novitātes. Jurista Vārds. 3.06.2014/NR. 22 (824)

42. M. Tipaine (2014). Šķ̄irējtiesu reputāciju grauj neitralitātes trūkums. Jurista Vārds, 3.06.2014/NR. 22 (824)

43. A. Fillers. Līgumiskās cesijas un šķīrējtiesas līguma mijiedarbība// Pieejams:

http: / / www . juristavards. Iv/doc.php?id=265042\&show=true 
